Article

\title{
Entrepreneurial Factors Affecting the Sustainable Growth and Success of a South African Construction Company
}

\author{
Abimbola Windapo ${ }^{(D)}$ \\ Department of Construction Economics and Management, University of Cape Town, Rondebosch 7700, \\ South Africa; abimbola.windapo@uct.ac.za; Tel.: +27-21-650-2049
}

Received: 3 April 2018; Accepted: 19 April 2018; Published: 21 April 2018

\begin{abstract}
The study examines a case of how the South African construction industry nurtured an entrepreneur and a large successful entrepreneurial construction company, even though the founder had no formal education and the company was founded during the Apartheid era. The question of whether entrepreneurs are born or are made is based on the age-old question of nurture or nature. The paper presents the narratives of the successful entrepreneur Mr. Sam Lubbe and the business strategy he used in growing a sustainable business. The information presented is collected through a case study research approach. The data collected suggests that although Sam does not have any formal education, he succeeded based on the nurturing given to him when he had the opportunity to work for a large South African construction company, his innate characteristics of self-confidence, task-result orientation, and originality, as well as his planning for the future and the use of a unique business model which helped him access international construction work opportunities. The study of this particular individual and his unique company is significant because it further validates previous research undertaken in other contexts and sectors on the traits of entrepreneurs and the success of companies.
\end{abstract}

Keywords: entrepreneurship; innovation; management; performance; sustainability

\section{Introduction}

This paper examines a case where the South African construction environment was able to nurture an entrepreneur and his large entrepreneurial construction company, even though the founder had no formal education. The construction industry plays a major role in the economy of any nation. This industry is very vital because of its characteristics. Firstly, it is large-sized. Secondly, it predominantly provides goods for investment. Thirdly, the government is the major client. In addition, the construction industry is the source one of the three basic needs of humanity (Maslow's Needs Theory) that is, shelter. It is evident from the number of small contractors operating in the construction industry that there is a belief that there is a greater return to be made from being an entrepreneur/ "tenderpreneur" than for working for others [1].

The term entrepreneur emerges from the French vocabulary meaning "to take" or "go between". Over the years, the word has evolved from referring to the landowners who exploited the resources on the land to inventors, creators, and businesspeople or undertakers usually associated with large government contractors. Carland et al. [2] described an entrepreneur as an individual who establishes a business concern for the principal purposes of profit and growth, is characterized principally by innovative behaviour, and employs strategic management practices in the business. The question of whether entrepreneurs are born or made is based on the age-old question of nature versus nurture. According to Seelig [3], knowledge is the toolbox for imagination. Imagination transforms knowledge into fresh ideas. This process is deeply influenced by resources, habitat, and culture. Meanwhile, 
attitude, which is shaped by an individual's beliefs and factual knowledge, is the spark that sets the entire innovation engine into action (see Figure 1).

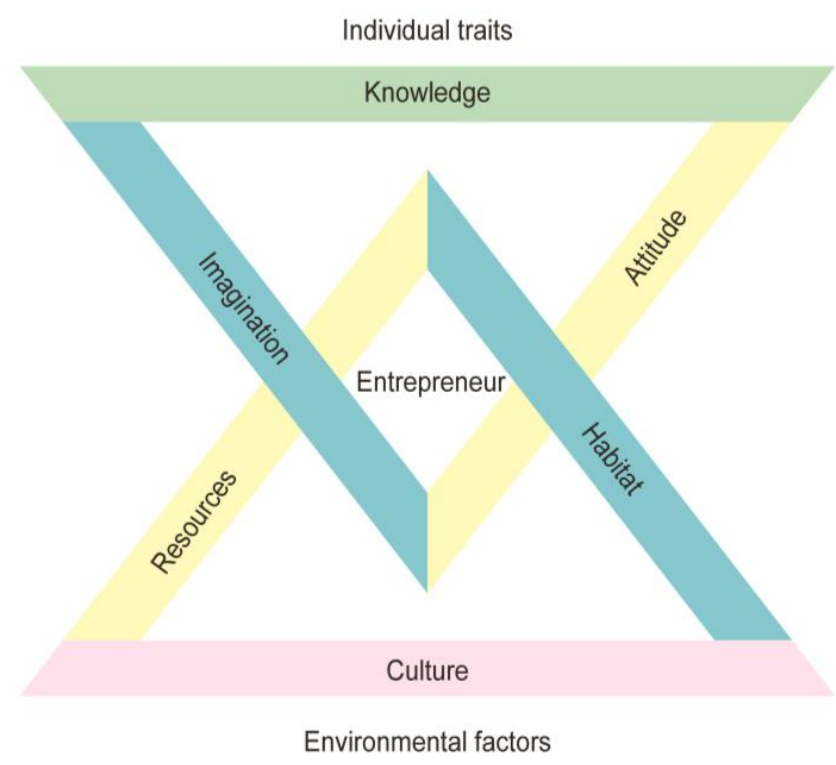

Figure 1. The internal traits and environmental factors that shape the entrepreneur (Seelig [3]).

The history of South Africa is one of segregation between the races and discrimination under Apartheid regime. As a result of this, individuals like Mr. Sam Lubbe, who founded the construction company examined in this study, were not able to access formal education and, coupled with poverty, this meant that they had to start work at a young age. Even though Sam had no formal education, during the Apartheid regime of the time in South Africa he was able to do the impossible, founding and developing a largely successful international construction company. The study reported therefore examines whether Sam acquired informal knowledge and used this knowledge for recognizing business opportunities and nurturing a largely successful international construction company. It also seeks to understand the characteristics and traits of this successful entrepreneur and how this individual validates/contradicts the findings of previous researchers on the traits of entrepreneurs. The paper presents an overview of the characteristics and traits of entrepreneurs and entrepreneurial activities, then outlines the research methods used in the study, provides the case study results and discussion, finally, gives the conclusions of the research.

\section{Overview of the Characteristics and Traits of Entrepreneurs and Entrepreneurial Activities}

This section reviews the features and traits that shape an entrepreneur and entrepreneurial activities in the following subsections.

\subsection{Entrepreneurs: Born or Made?}

The model shown in Figure 1 will be used in understanding the concept of innovation and entrepreneurship because an entrepreneur is also an innovator. Seelig [3] posits that there are two parts to the innovation engine- the environment and individual traits. According to Seelig [3], knowledge is the toolbox for imagination. Imagination transforms this knowledge into fresh ideas, and this process is deeply influenced by resources, habitat, and culture. Meanwhile, attitude, which is shaped by an individual's beliefs and factual knowledge, is the spark that sets the entire innovation engine into action.

It can be surmised from the presentation made by Seelig [3] that education is not enough to provide a person with the knowledge base required to recognize innovation and potential business opportunity. 
While a solid education can help an individual in their ability to recognize a business opportunity, the educational system is linear and one-dimensional, and is not flexible enough to encourage an entrepreneurial spirit to be realized. Knowledge is intangible, boundaryless, and dynamic and consists of two types-explicit and tacit [4]. The tacit knowledge is that which has been instilled into his/her mental faculty from a young age and is deep-rooted in solid education, upbringing, life experiences, and exposure (resources, habitat and culture). This knowledge helps an individual in their ability to recognize business opportunities. However, the individual must also be able to turn that opportunity into reality, and this is where his attitude to and passion for a particular endeavour comes into play. The education/knowledge acquired helps a person foster these characteristics, but it is ultimately the person who must pursue their development or simply recognize their existence. This study will seek to find out what tacit knowledge was acquired by the founder of Lubbe and Company to enable this entrepreneur to see business opportunities and develop a large construction company.

While Zawdie [5] mentions that innovation occurs through organizational learning, knowledge accumulation, and knowledge-sharing, Egmond [6] states that knowledge accumulation and learning is a driver for innovation. Therefore, the occurrence of innovation would be expected to be highly likely where there is "cultural readiness" arising from exposure to new ideas and practices.

The central role of entrepreneurial leaders is business creation, which calls for a dual-level analysis: individually, analysing psychological aspects and social factors or non-psychological ones, and at an environmental level [7].

\subsection{Characteristics and Traits of Entrepreneurs}

Entrepreneurs are people who have developed the ability to see and evaluate business opportunities, to gather the necessary resources, to take advantage of the resources gathered, and to initiate an appropriate action plan to ensure success. The entrepreneurial process is faced with a diversity of approaches, which makes it difficult to appraise the concept and define who entrepreneurs are [8]. An entrepreneur could be operationally defined in this study following Carland et al. [2], as an individual person who sets up a business or businesses, taking on financial risk for the principal purposes of profit and growth, who is characterized principally by innovative behaviour, and employs strategic management practices in the business.

From the above definition, it is evident that entrepreneurs are action-oriented, highly motivated individuals who take on risks to achieve the goals of the business. According to Fini and Grimaldi [9], the entrepreneurial intention is a cognitive representation of the actions to be implemented by individuals to either establish new independent firms or create new value in existing ones. Soriano [7], notes that the study of entrepreneurs as individuals analyses the factors that explain their appearance, such as personal characteristics of their psychological profile (the need for achievement, the capacity to control, power and independence, tolerance of ambiguity, and a tendency to take risks). Entrepreneurs also need certain qualities that are both psychological and sociological, or personal, and according to Soriano [7] these consist of creativity, proactiveness, and personality. The list of characteristics and traits presented in Table 1 provides a working profile of entrepreneurs.

Table 1. Characteristics and traits of entrepreneurs.

\begin{tabular}{cl}
\hline Characteristics & \multicolumn{1}{c}{ Traits } \\
\hline Self confidence & Confidence, individuality, optimism \\
\hline Task-result oriented & $\begin{array}{l}\text { Need for achievement, profit-oriented, persistence, perseverance, determination, hard } \\
\text { work, drive, energy, initiative }\end{array}$ \\
\hline Risk-taker & Risk-taking ability, likes challenges \\
Leadership & Leadership behaviour, gets along with others, responsive to suggestions and criticism \\
Originality & Innovative, creative, flexible (openness of mind), resourceful, versatile, knowledgeable \\
Future-oriented & Oversight, perceptive
\end{tabular}


Table 1 lists traits that individuals possess or which individuals have potential to develop after Soriano [7]. This study postulates that individuals may not have all these traits. However, the more they have, the greater the chances of becoming an entrepreneur. Many of these traits are highly inter-related. For example, people who are self-confident will probably accept responsibility for their own decisions, be willing to take on risks, and become leaders. When these traits are enhanced and developed over a period, this leads to a mindset change/turn around. This study assumes that not all entrepreneurs are alike, either in these 25 traits listed or in their qualities. According to Carland et al. [2], when evaluated with respect to various personality traits and skills, it is clear that as a group, entrepreneurs differ substantially from non-entrepreneurs. The second objective of the study was to establish the characteristics and traits of Mr. Sam Lubbe and how many of these can be aligned to those of the entrepreneurs listed in Table 1.

While some scholars have voiced skepticism concerning whether or not leaders can make a difference in organizational performance [10-12], others have found that leadership is critical to the survival of any organization [13-16]. According to Soriano [17], the relationship between the enterprising character of the business, its size, and innovation has been going on for some time. Soriano [17] established the possible relationships between the character of the businessman and the success of their businesses. This study reports that leadership is significant, especially with respect to its effect on organizational performance, and that good leadership leads to success, efficiency, effectiveness, and improved performance, all of which result in higher profitability. The study also concludes that the corporate success of leaders in the construction sector is dependent on the ingenuity of the Chief Executive Officer.

Human behaviour and attitude is a combination of hereditary (inherited or inborn factors such as genetic characteristic) and environmental factors (those things we learn from other people and places in the form of the manner of speaking, walking, work ethics, and so forth). The study assumes certain behaviours or characteristics in a leader, such as trust, contentment, commitment, determination, dedication, discipline, savvy, integrity, strong work ethic, fairness, honesty, empathy, and sharing attitude, lead to positive organizational growth, while misplaced behaviour or characteristics, such as acquisition syndrome, greed, envy, jealousy, selfishness, apathy, unnecessary competition, arrogance, and dishonesty, lead to negative growth.

Soriano [17] noted that while some researchers base their studies on the assumptions that the entrepreneur "is born not made" and therefore anybody displaying the characteristics outlined in Table 1 is almost predestined to take on this role, for other researchers it is a contextual event resulting from the influence of cultural, economic, sociological, and psychological factors. This study argues that the growth of Lubbe Construction Company is attributable to both the character and traits of the founder, and the informal unstructured tutelage received by the founder in the South African construction industry during the Apartheid era.

\subsection{Overview of Factors Aiding Construction Company Performance}

Stinchcombe [18] and Eisenhardt and Schoonhoven [16], found that a factor underlying the failure of young organizations is due to their limited resources, and consequently if resources are abundant, they will grow. Evaluating the European Union support for innovation in Spanish Small and Medium Enterprises (SMEs), Romero-Martinez et al. [19] found that access to finance is one of the biggest structural problems identified by SMEs, noting that only a small percentage of firms opt for funding from the European Union (EU) because they often perceive the loss of control of their companies as unacceptable.

Soriano [7] found that social or non-psychological factors such as education and training, experience, networks, and family are important factors that influence performance improvements and entrepreneurial success, highlighting that there is a correlation between investment in human capital and obtaining and maintaining business performance. This is corroborated by Deakins et al. [20] who established that education has a positive influence on performance. 
This study argues that though the education received by the founder of Lubbe was unstructured, with limited financial resources, there are certain personal characteristics and social factors that enabled the sustained growth and success of the company that he founded.

\section{Research Methods}

The study employed a case study approach in eliciting research information from the founder and Chief Financial Officer of Lubbe Construction (Pty) Ltd. (Germiston, South Africa), a large construction company listed in Grade 9 General Building and Civil Engineering (Potentially Emerging) in the Construction Industry Development Board (cidb) Register of Contractors in South Africa. Personal interviews were conducted with Mr. Sam Lubbe, the Chief Executive Officer, and Chief Financial Officer of the company respectively, using an interview protocol. The purpose of the interview was to document and develop an understanding of how the company was started, the type of knowledge acquired by Sam, and the personal traits, characteristics, and ingenuity that enabled the establishment and development of a widely successful international construction company during the Apartheid in South Africa. The personal interview was the main instrument used in the investigation. The interview was administered by visiting the respondents at their place of work. The type of information required was sent to the respondents in advance with the request for an interview invite. The interview protocol, addressed to the $\mathrm{CEO} /$ founder of the company, was administered on the condition that this individual also held this position at the time the firm was established.

The steps followed in the data collection were as follows: Historical case material was also gathered and a "story" covering technological progress as well as business and construction processes was obtained from the company; Basic information on the business's history, number of employees, turnover, product markets, technologies, leadership type, and resources required was also checked and updated during the interview; data collected was supplemented (in advance of the interview) by secondary sources (mainly the company annual reports), web searches of business news, and stock market analysts' assessments.

In particular, answers were sought to the following questions:

1. What was the experience and knowledge of the founder before setting up the company?

2. What was the mission of the founder in establishing the company?

3. What were the strengths/capabilities of the founder at inception?

4. What factors aided the growth and success of the construction company in terms of the characteristics and traits of the founder?

Sample and Result Limitations: It should be noted that the ability to generalize the findings of this study to the population of successful cidb-registered contractors or population of contractors is limited. However, the results of the case study are probably indicative of what would be found in the larger population.

A case study of Lubbe Construction (Pty) Ltd. was undertaken because it is a unique business. Unlike other companies founded by more advantaged groups, Lubbe Construction was established in 1981 by an individual who was from the disadvantaged black group, which was denied access to opportunities in South Africa because of Apartheid laws. There is no suitable comparator that can be used in aggregating this company to other successful white-owned construction companies established at the same time in South Africa. The story of the company is the focus of the study. According to Soriano [17], studies on business set-up and functioning —or entrepreneurship — generally use homogenous samples in order to better understand the object of the study. Furthermore, it is acknowledged that no universal unit of analysis exists for describing or measuring the performance of firms. According to Soriano [7], some experts go as far as to establish business success or failure according to whether the firm survives or not. Lubbe and Construction (Pty) Ltd. is therefore considered to be successful because it has been in operation for more than 36 years. 


\section{Case Study Results and Discussion}

This section is divided into the following subheadings.

\subsection{Company Profile}

Lubbe Building and Electrical Contractors South Africa was founded in 1981 when Sam Lubbe started out with a one-man operation, installing electricity in homes when the greatest part of Soweto Johannesburg South Africa, was as yet un-electrified. Sam used his R1500 severance pay and his R 2000 savings to purchase materials for his electrical installation contracts in 1981 (R stands for the South African Currency - Rands (ZAR)). According to Sam, "at that time, Soweto was in the process of being electrified, and I was able to grow the business by installing electrical outlets in households". By 1985, his capital had grown to R 43,000, which served as the initial funding for his first two outbuildings in Soweto. The company expanded its horizons internationally, setting up businesses and offices in Botswana, Mozambique, Sudan, and England and has shown exceptional growth and leadership not only in its home country of South Africa but internationally. The company's gross turnover was more than 200 million Rand for the year ended February 2016. Lubbe Construction is active in the provision of housing, building and civil engineering infrastructure. Bonded properties form a large part of its housing portfolio. In recognition of the company's efforts, it has been awarded the South African National Award for Best Emerging Builder and for Outstanding Performance and Service in the Provision of Housing, as well as the Southern African Entrepreneurial Development Award of 1999.

\subsection{Experience and Knowledge of the Founder before Setting up Lubbe Construction Company}

Mr. Sam Lubbe entered the building industry at the age of 12 after failing Standard One and worked first as a tea-boy, then on site as a labourer. According to Sam, he speaks "Kitchen English". He also learnt the skills of bricklaying and plastering. Assisting the foreman as a toolbox boy, and Electricians on-the-job, he was able to read plans and electrical drawings. According to Sam, "I was a toolbox boy carrying the tools, I used to assist the foreman in doing the measurement for buildings, using the plan, tape-measure and started getting experience. He (the foreman) was also doing electrical, and so, I know how to do the electrical installation and how to build".

Sam gained rapid promotion in the company such that by the time he was 19, his boss gave him a company car for transporting his team. He was responsible for quality control. Sam mentions that he was in charge of checking the quality of the work and preparing the snag list. He went through the building and recorded his observations in a tape recorder in the local Zulu language. The tape was transcribed and translated into English at the office and used in preparing the snag list. His boss had so much confidence in his report that he became the last line of quality control. He opined that "now if I say the job is okay, my boss can book for handover, because if I say it is good, everybody if they come there, they will agree that it is good".

Within the space of four years, Sam was able to read house plans and electrical drawings and do quality control. When he was retrenched for being highly paid in 1981 (his salary was R 25 per week), he had worked for the company for 12 years, and given a severance pay of $R 1500$. The only weakness acknowledged by Sam at the inception of Lubbe Construction was the fact that he was uneducated. Incidentally, the company that was instrumental in nurturing Sam closed shop according to him a long time ago. The company failed where his-the Lubbe Construction Company-is now succeeding. Sam's boss was instrumental in the establishment of his business. Upon his advice to open a construction company, Sam asked his boss how he expected him to open a company with no money. The boss told him "you are very clever and can do something".

The interview conducted with Sam suggests that he acquired tacit knowledge, which is highly personal and deeply rooted in an individual's actions and experience [4]. This tacit knowledge was 
gained in the technical dimension-which encompasses the kind of simple personal skills or crafts often referred to as "know-how".

\subsection{Mission of the Founder in Establishing the Company and Entrepreneurial Intention}

To understand Sam's entrepreneurial intention, he was asked to provide an indication of his mission and vision for the company at inception. Sam stated that his mission was to be his own boss, and make enough money to buy a "bakkie" (a pick-up truck). His aspiration embodied in his vision for the company showed a quest for survival on a monthly basis and later on, on a yearly basis. He did not appear to have long-term goals.

Sam was so steadfast in his vision that after two years in the business, he did not realise he had made enough money to buy a "bakkie". He recounted that his former boss enquired after his progress and demanded to see his savings account book. Sam's boss did not believe him when Sam told him he had about R 50,000 in his savings account. The boss commended him on this achievement and said: "now you will have to buy a bakkie". The boss then took him to a car dealer, and he bought a Ford Cortina "bakkie". Before that, Sam used a bicycle as his mode of transport (see Figure A1 in Appendix A). Sam recognised the need to establish a construction company to fulfil his quest to be his own boss.

\subsection{Strengths and Capabilities of the Founder at Inception}

It emerged that the key resources possessed by Sam at the inception of his company (Lubbe Construction), were the necessary specialist expertise and technical ability in construction, the ability to spot quality, a unique ability to persuade people to do what he said, and innovative abilities. He always found new ways of doing the same thing and was able to spot a need. He also had the financial strength and access to finance that suited his unique business model.

Sam confirmed that these resources were used to the advantage of the company at inception. Sam used the balance of R 25,000 he had after purchasing his "bakkie" as the seed capital for his construction business. When he went to the bank to enquire whether the bank would provide a mortgage for the customers that he brought from the Soweto Township, the bank informed him that this would not be possible because of his age and because he could run away if funds were advanced to him. He (Lubbe) told the bank that he had some funds (R 25,000) and he would use his money to build a garage and two rooms for his clients. All he wanted was for the bank to approve his customers' mortgage applications. He was asked how much he would charge customers for this service, to which he replied R 12,000, and therefore, he would start with only two customers. The bank found this agreeable and said to Sam "as long as you use your money in the first instance, we will approve your clients' bond when the bond is approved, you go and build with your money, and then our inspector will come and inspect. If you finish and the job is nice, then we will recommend that you build houses for the bank".

It can be inferred from the preceding that Lubbe construction had the financial capacity and access to finance a primary construction resource at inception [7]. This mirrors Stinchcombe's [18] and Eisenhardt and Schoonhoven's [16] findings that lack of access to finance is often a factor underlying the failure of young organizations, and that company growth is dependent on sufficient funding.

\subsection{Factors that Aided the Growth and Success of Lubbe Construction Company-Characteristics and Traits of the Founder}

It also emerged from the study of Lubbe Construction that certain features and traits, the unique abilities and personality, and the strategic decisions made by Sam at the inception and during the lifetime of the company were crucial to the company's survival, growth and success. This finding is aligned with the results of previous studies by [13-16] that leadership is essential to the survival of any organization. Sam exhibited a combination of two leadership styles. One was strategic: the style of one who knows how to comply with the company's mission and vision. The other was authentic: the style of a leader "who is" — someone who does not pretend to be a leader simply because they 
hold a leadership position. Rather, as founders of companies, they have to steer employees in the direction they believe they should go. Sam was also described by an employee (the Chief Financial Officer) as providing, in addition to the above, visionary leadership, that is both charismatic and transformational, with the effect of motivating their followers. Based on the concept of how leaders execute their functions, Sam was described as both an employee-oriented (democratic) and production oriented (autocratic) leader. It was acknowledged that he provides some rewards and benefits to his employees, such as bonuses whenever they exceed a given target, empowerment, pension funds, death benefits, and training, while at the same time focussing on delivering quality and timely services to clients. His employee noted that Sam built up a culture of teamwork, and commitment to his vision for the company among his staff.

Following the company interview, in which Sam and his employee were asked to describe his leadership values and convictions, it emerged that Sam is described as having a well-mannered disposition. Sam saw himself as a hardworking, honest and trustworthy, disciplined, and task-result oriented person. The interview findings also suggest that Sam is quite productive, thrifty, and not covetous, with an ability to increase profits and turnover, ploughing back profits into the business. He will not use the company revenue/profits for anything that is considered unproductive/frivolous. For example, he continued using a bicycle to transport his building materials for more than two years, even though he had accumulated enough money to buy a "bakkie". He seemed to view a personal vehicle as a bad investment.

\subsection{Innovative Business Model and Strategy Used by the Founder of Lubbe Construction in Achieving a Competitive Advantage}

Lubbe Construction got its first real big break when the Perm Building Society offered $100 \%$ mortgage bonds to any of their (Lubbe Construction Company) clients wishing to make improvements to their properties. Furthermore, by 1990, on the recommendation of the Perm Building Society, based on his high standards of workmanship and integrity, Lubbe Construction was awarded a major contract to build a high-rise block of flats in Israel, and this is where according to him, the business took off (a turning point). Sam notes that "I used my savings to build a two room and a garage house, we built two of them, the bank came to inspect-they passed. They said that the job is very nice, they registered the client's bond the next week, and after the bond was registered, the bank paid me all my money". When he requested to know from the bank how much money they wanted his clients to pay as a deposit, the bank officials told him, "Sam, we do not need a deposit, as long as you build it, we pay you, and then the owner can pay us".

The innovative business model and management strategy used by Sam in creating work opportunities for Lubbe Construction followed a multilateral process: Sam looked for customers who were desirous of owning a home in Soweto township; he used his money to build a two-room house and garage which met the clients' requirements; he took the clients to the bank; the housing customers and the bank signed a bond agreement using the house as surety; Lubbe construction was paid once the bond was finalized: and the client started paying back his bond/mortgage in instalments to the bank. There was no loser, only a win-situation. According to Sam Lubbe, he came out stronger. In housing construction adverts, which he distributed at the Railway Station; he averred that Lubbe Construction could build two rooms and a garage with no deposit for R 12,000. People started applying through his company for houses, and within a short space of time, his business became a household name. After getting enough customers, Sam, through the Lubbe Construction Company started buying tracts of land for housing development. Lubbe Construction Company expanded organically to include buying its property for development and other related business ventures.

The data collected is aligned to the findings of Seelig [3] and presented in Figure 1. It suggests that there are environmental factors such as culture, habitat and resources that shape the mind-set of an innovator/entrepreneur. In the case of Sam, the company (environment) in which he worked for 12 years nurtured and made it possible for him to acquire the technical skills that he needed to survive 
in the construction business. Sam also had a positive attitude to life; he was attentive, perceptive and future-oriented, resourceful, creative, and a risk-taker. These traits, coupled with the environment within which Lubbe was nurtured (though this happened mostly during the period of Apartheid in South Africa, the Soweto uprising, and black power), helped shaped Sam into an entrepreneur of note, who built a successful black construction business from nothing at a time when there were few black construction businesses.

In the course of the interview, he mentioned the fact that he was awarded a 15-storey-building contract by the Israeli government in 1990. He spent two years in Israel with 60 bricklayers and labourers. He came about this project because of his exceptional track record with the Perm building society that recommended his company, and because the Israeli government was looking for a black construction business to which they could award the construction contract. Getting a black construction company was such an uphill task for the Israeli government that they had to look for one in Apartheid South Africa.

\section{Conclusions}

The paper presents the narratives of a successful business (Lube Construction) and entrepreneur Mr. M.S. Lubbe. The study examines how the South African construction industry nurtured the entrepreneur and the growth of the large entrepreneurial construction company, even though the founder, Mr. Sam Lubbe, had no formal education. The paper examined the question of whether entrepreneurs are born or are made based on the age-old question of nurture versus nature. The study also assessed how the individual validates the findings of previous research on the traits of entrepreneurs and entrepreneurial activities, and how this impacts on sustainable growth and success in the South African construction industry. The study found evidence to support the fact that the entrepreneur studied had the right disposition and was nurtured in the right environment. The data collected suggests that although the individual does not have any formal education, he succeeded based on the nurturing given to him when he had the opportunity to work for a large South African construction company and his innate characteristics of self-confidence, task-result orientation, and originality, as well as his planning for the future and unique business model and management strategy, which helped him access international construction work opportunities. In the case of Lubbe Construction Company, the interaction of nature and nurture made it possible for its founder Sam to establish and grow a large sustainable construction enterprise. This study is aligned with and confirms the findings of earlier studies by Soriano [17], although these used a quantitative approach in a different context (Europe). This study ascertains the entrepreneurial factors and activities contributing to the sustainable growth and success of a construction company and its strength lies in a methodology that links the concept of entrepreneurship to management strategy and business performance in the construction industry. Based on these findings, the study hypothesizes that formal education is not a key entrepreneurial factor necessary for individuals desirous of establishing successful companies in the construction industry. The study limitation is that the results obtained cannot be generalized to all successful construction companies in the study area due to the use of a case study research approach in obtaining data. Therefore, further studies will be required to test this hypothesis, using a larger sample size and a quantitative research approach.

Far from his humble beginnings as a young tea boy and entrepreneur riding to sites on a bicycle, Sam presently sits at the top of a successful construction business. Thanks to hard work, dedication, and entrepreneurial ability, his small start-up company has grown and now has branches in Botswana, Mozambique, Sudan, and England.

Acknowledgments: The author acknowledges Sam Lubbe, the founder and CEO of Lubbe Construction company for accepting to be interviewed. The work is based on the research supported in part by the National Research Foundation of South Africa (Grant Number: 99403) and the cidb. The opinions expressed, and conclusions arrived at, are those of the author and are not necessarily to be attributed to the NRF or the cidb.

Conflicts of Interest: The author declares no conflict of interest. 


\section{Appendix A}



Figure A1. Sam transporting building materials on his bicycle (his first mode of transport).

\section{References}

1. Construction Industry Development Board (CIDB). The Construction Industry as a Vehicle for Contractor Development and Transformation; Industry Report; CIDB: Pretoria, South Africa, 2012.

2. Carland, J.W.; Hoy, F.; Boulton, W.R.; Carlaland, J.C. Differentiating Entrepreneurs from Small Business Owners: A Conceptualization. Acad. Manag. Rev. 1984, 9, 354-359.

3. Seelig, T. The Innovation Engine; Stanford Executive Briefings Video: California, USA, 2012.

4. Nonaka, I.; Konno, N. The Concept of "Ba": Building a Foundation for Knowledge Creation. Calif. Manag. Rev. 1998, 40, 40-54. [CrossRef]

5. Zawdie, G. Construction Innovation through Change Management. In Introduction to Construction Innovation; Akintoye, A., Goulding, J., Zawdie, G., Eds.; John Wiley: London, UK, 2012; p. 19.

6. Van Egmond, E. Innovation, Technology and Knowledge Transfer for Sustainable Construction. In Introduction to Construction Innovation; Akintoye, A., Goulding, J., Zawdie, G., Eds.; John Wiley: London, UK, 2012; p. 95.

7. Soriano, D.R. Management factors affecting the performance of technology firms. J. Bus. Res. 2010, 63, 463-470. [CrossRef]

8. Gartner, W.B. "Who is an Entrepreneur?" Is the Wrong Question; Educational Foundation, University of Baltimore: Baltimore, MD, USA, 1986.

9. Fini, R.; Grimaldi, R. The Foundation of Entrepreneurial Intention. In Proceedings of the Summer Conference at CBS-Copenhagen Business School, Frederiksberg, Denmark, 17-19 June 2009.

10. Pfeffer, J. The Ambiguity of Leadership. Acad. Manag. Rev. 1977, 2, 104-112.

11. Salancik, G.R. Commitment and the Control of Organization Behavior and Belief. In New Directions in Organizational Behavior; Staw, B.M., Salancik, G.R., Eds.; St. Clair: Chicago, IL, USA, 1977; pp. 1-54.

12. Shamir, B.; House, R.J.; Arthur, M.B. The Motivational Effects of Charismatic Leadership: A Self-Concept Based Theory. Organ. Sci. 1993, 4, 577-591. [CrossRef]

13. Albert, K.J. Straight Talk about Small Business; McGraw-Hill: New York, NY, USA, 1981.

14. Stegall, D.P.; Steinmetz, L.L.; Kline, J.B. Managing the Small Business; Richard, D., Ed.; Irwin: Homewood, IL, USA, 1976.

15. Covin, J.G.; Slevin, D.P. Strategic Management of Small Firms in Hostile and Benign Environments. Strateg. Manag. J. 1989, 10, 75-87. [CrossRef] 
16. Eisenhardt, M.K.; Schoonhoven, C.B. Organizational Growth: Linking Founding Team, Strategy, Environment and Growth among U.S. Semi-Conductor Ventures, 1978-1988. Adm. Sci. Q. 1990, 35, 504-529. [CrossRef]

17. Soriano, D.R. Modelling the enterprising character of European firms. Eur. Bus. Rev. 2003, 15, $29-37$. [CrossRef]

18. Stinchcombe, A. Social Structure and Organizations. In Handbook of Organizations; March, J.G., Ed.; Rand McNally: Skokie, IL, USA, 1965; pp. 142-193.

19. Romero-Martinez, A.M.; Ortiz-de-Urbina-Criado, M.; Soriano, D.R. Evaluating European Union support for innovation in Spanish small and medium enterprises. Serv. Ind. J. 2010, 30, 671-683. [CrossRef]

20. Deakins, D.; Glancey, K.; Menter, I.; Wyper, J. Enterprise education: The role of head teachers. Int. Entrep. Manag. J. 2005, 1, 241-263. [CrossRef]

(c) 2018 by the author. Licensee MDPI, Basel, Switzerland. This article is an open access article distributed under the terms and conditions of the Creative Commons Attribution (CC BY) license (http://creativecommons.org/licenses/by/4.0/). 